\title{
Online Learning in Higher Education to Encourage Critical Thinking Skills in the $21^{\text {st }}$ Century
}

\author{
Dewi Kusuma Wardani¹, Trisno Martono², Laurensia Claudia Pratomo ${ }^{3}$, Duta Sabiila \\ Rusydi $^{4}$, Dwi Hendra Kusuma ${ }^{5}$
}

\begin{tabular}{l} 
ARTICLE INFO \\
\hline Article History: \\
Received 09.09.2018 \\
Received in revised form \\
28.12 .2018 \\
............................... \\
Available online 01.04 .2019
\end{tabular}

\begin{abstract}
This research aims to examine the effectiveness of online learning information system to improve undergraduates' critical thinking skills in learning macroeconomics through two instruments, test and questionnaire. Quantitative method was applied in this research. The research was conducted in the State Isla mic Institute of Sala tiga and Sebelas Ma ret University involving 120 undergraduates. There is a difference in the mea n post-test score of the control and experimental class. Besides, $N$-Gain shows that there is lea rning outcome improvement in experimental class, taught by using online learning information system, of both the State Islamic Institute of Salatiga and Sebelas Maret University. This research finding is supported by the result of the questionnaire on the critical thinking skills and the effectiveness of online learning media. It is found that there is significant and strong correlation between information system media and and critical thinking skills. Based on the research findings, online information system media is effective to improve undergraduates' learning outcome and critical thinking skills in learning macroeconomics.
\end{abstract}

Keywords:

Critical Thinking, Learning Media Innovation, Web-based Learning Information System.

\section{INTRODUCTION}

Critical thinking is a high level skill important to solve complicated and sharp problems that need indepth analysis. Critical thinking as cognitive skills requires logical and well-structured idea to solve problems (Dwyer, Hogan, \& Stewart, 2014). The skills emphasized cover analyzing, evaluating, and synthesizing. Critical thinking skills can be measured through cognitive test by using mean score as the achievement criteria as critical thinking is always associated with achievement (Van der Wal, 2000).

Critical thinking assists undergraduates in getting good academic achievement. It is also emphasized by higher education so that critical thinking has an important role in learning (Ramsden, 1992; Fox.H, 1994; Marton, 1997; Bensley, 1997; Facione, 2008). Undergraduates' critical thinking is indeed suitable to solve problems that involve mathematical and graphical approach as what is found in macroeconomics learning. Macroeconomics combines economics understanding and mathematical skills. High level analy sis in understanding the correlation among certain concepts is needed to solve complicated problems. Macroeconomics evaluation results on the undergraduates of the State Islamic Institute of Salatiga and Sebelas Maret University are unsatisfying. Most of undergraduates face difficulty in understanding the material especially which is related to graphical and mathematical analysis. $68 \%$ of undergraduates' competence scores are below the passing grade which is 70 . Therefore, there should be remedial teaching. This show s that undergraduates' critical thinking skills should be improved (Nabila, R., 2018; Wardani, D.K., 2018). Macroeconomics learning is characterized by in-depth concepts understanding as well as mathematical and grapical analysis in solving economics problems. Therefore, it is really important for the undergraduates to have good critical thinking skills (Van der Wal, 2000).

In learning macroeconomics, undergraduates still use old edition books. It costs a lot to buy new edition books that will support their learning. Information technology is not utilized maximally in their learning either. The way to improve the learning quality that eases undergraduates to access the material anywhere and anytime is online learning innovation (Nabila, R., 2018; Wardani, D.K., 2018).

\section{Literature Review}

Information and communication technology used in educational field is known as e-based learning. Ebased learning displays new features such as multimedia-based learning (text, visual, audio). The use of 
media in learning process is one of some ways that can be used to improve learning quality (Tania, K.D., \& Ibrahim, A., 2011).

Undergraduates have more motivation to learn when they are able to interact with module and multimedia that help them to understand the topic learnt better (Heidi, 2015). As stated by Sutopo (2003:23), multimedia computer creates effective learning if various components (text, chart, audio, video, animation, simulation, or photo) are interatively combined. Munir (2009:235) states that the benefits of using multimedia are 1) multimedia provides convenience in giving feedback; 2) multimedia allows learners to freely choose learning topics; and 3) multimedia offers easy and systematic control tow ards learning process. Based on the previous ideas, it can be concluded that computer-based multimedia creates new, interactive, effective, efficient, and attractive teaching learning atmosphere.

To improve undergraduates' learning outcome, more effective and efficient learning strategies are needed including the use of learning media to positively support their learning process. Based on The Partnership for $21^{\text {st }}$ Century Living in Frydenberg and Andone (2016), information and technology literacy should be effectively implemented by (1) using technology as a research instrument as well as to evaluate, control, and share information; (2) using digital technology (GPS, computer, media player, and others), communication device, and social media that can be accessed, managed, and integrated based on its function in education; and (3) having basic knowledge on the use of technology. Thus, in selecting the media, all components of lesson plan such as objective, material, approach, method, evaluation, and learners' profile should be taken into account.

Online learning information system is one of media utilizations. The development of online learning information system eases the undergraduates to access materials from different sources. Online learning information system is selected as a supportive media since most of the undergraduates use internet to communicate and interact. They also have social media so that learning media is adjusted to their interest. Internet is a kind of facility that can be used to improve learning (Tania, K.D., \& Ibrahim, A., 2011).

This research is blended learning theory development from a research done by Heidi (2015). Heidi's finds out that a kind of learning that correlates learning material with real events improves learners' skills in solving problems so that they aquire communication and critical thinking skills, especially when their learning is supported by the use of website (online system) that integrates technology and learning. Learning will be efficient if learners make use of website to practice (Collis and Van der Wende, 2002) since they can re-open and repeat learning materials through website online (Kerdprasop and Kerdprasop, 2008). According to Arsyad (2007: 12), good learning media have three main characteristics which are fixative, manipulative, and distributive. Fixative is characterized by the media abilities to store, preserve, or reconstruct a phenomenon. Manipulative is typified by its abilities to transfer various phenomena in different, attractive, and straighforward contexts. Meanwhile, distributive has something to do with the media abilities to repetitively show a phenomenon evenly to all learners without losing its essence.

The effectiveness of online learning information system is important to be identified to solve higher education problems so that the learning becomes more effective and the undergraduates are encouraged to think critically and learn independently.

\section{Research Objective}

This research aims to examine the effectiveness of online learning information system to improve undergraduates' critical thinking skills in learning macroeconomics. Based on this research objective, the problems are formulated as follows: (1) Is online learning information system able to improve critical thinking skills?; (2) Does the use of online learning information system encourage undergraduates critical thinking skills?

\section{METHODOLOGY}

120 heterogeneous with an average age of 19 years undergraduates of the State Islamic Institute of Salatiga and Sebelas Maret University who learn macroeconomics were involved in this research. The approach implemented in this research was quantitative approach. The data analysis technique used to examine the media effectiveness tow ards learning outcome improvement view ed from critical thinking skills 
and to identify the effect of using macroeconomics learning information system media towards undergraduates' critical thinking skills was descriptive quantitative analysis. Hence, pre-test and post-test mean score on both control and experimental class were tabulated and compared to know the media effectiveness tow ards learning outcome improvement view ed from critical thinking skills. The data collected from the questionnaire on the influence of macroeconomics learning information system media towards critical thinking skills were also analyzed and tabulated.

\section{Research Instrument}

There were two instruments used in this research which were test and questionnaire. Those two instruments were used to examine the effectiveness of online learning information system in improving learning outcome viewed from undergraduates' critical thinking skills. Critical thinking skills can be measured through cognitive test. Cognitive test can be used to measure critical thinking skills since that type of skill is always related to academic achievement (Van der Wal, 2000). There were 20 items related to graphical and mathematical analysis in the pre-test and post-test. The items were made based on Bloom Taxonomy. To emphasize critical thinking skills improvement, the items referred to C4 (analyze), C5 ( evaluate), dan C6 ( synthesize).

Meanwhile, the questionnaire on online learning information system towards critical thinking skills covered 48 items in the from of statements. The statements included two variables, critical thinking and online learning information system effectiveness. The questionnaire applied 4-point likert scale (4)"strongly agree", (3) "agree", (2) "disagree", and (1) "strongly disagree". The research instrument was arranged based on the two main variables which were critical thinking and online learning information system effectiveness. The first variable which was critical thinking covered three indicators: (1) Confidence in critical thinking; (2) Valuing critical thinking; (3) and Misconceptions (Stupple, Maratos, Elander, Hunt, Cheung, \&Aubeeluck, 2017). Meanwhile, online learning information system effectiveness covered five indicators as follows: (1) Students' behavior and attitude; (2) Technology/system; (3) Interactive applications; (4) Institutional; and (5) Instructors' characteristics (Poon, Lock-Teng Low , \& Gun-Fie Yong, 2004).

\section{Data Analysis}

The data on the effectiveness of online learning information system to improve undergraduates' learning outcome were analyzed after the data normality and homogeneity were tested. The normality and homogeneity of the data were tested by using IBM SPSS Statistics 23 program. T-test was also used to know the mean score difference between experimental and control class. The researchers also applied Gain analysis technique to know the undergraduates' learning outcome (knowledge). Gain was obtained by comparing the test score before and after the treatment. Gain score was measured by using the formula as follows (Hake, 1998):SG=(S_post-S_pre)/(S_maks-S_pre) while the learning outcome improvement was categorized into three criteria: high $(\mathrm{g}>0.7)$, medium $(0.3 \leq \mathrm{g} \leq 0.7)$, and low $(\mathrm{g}<0.3)$. The effectiveness on the use of media towards undergraduates' critical thinking skills could be also seen from the questionnaire distributed to undergraduates' in experimental class. The instrument was adapted from the research conducted by Stupple, Maratos, Elander, Hunt, Cheung, \& Aubeeluck (2017) and Poon, Lock-Teng Low, \& Gun-Fie Yong (2004). The influence was analyzed by using IBM SPSS Statistics 23 program through simple regression analysis. Simple regression analysis required validity, reliability, and classical assumption test. If $\mathrm{r}_{\mathrm{o}}$ is higher than $\mathrm{r}_{\mathrm{t}}$, the correlation between the two variables were significant.

\section{FINDINGS}

\section{Critical Thinking Skills Improvement Viewed from Learning Outcome}

The level of significance in this research is 0,05 . The research is conducted in the State Islamic Institute of Salatiga (IAIN) and Sebelas Maret University (UNS). Based on normality pre-test on the control class of IAIN, it is found that Kolmogorov-Smirnov Sig value is $0,017>0,05$ and Shapiro Wilk Sig value is 0,184 > 0,05 ; while on the experimental class of IAIN, Kolmogorov-Smirnov Sig value is 0,164>0,05 and Shapiro Wilk Sig value is $0,077>0,05$. These indicate that the pre-test scores on both control and experimental class of IAIN are normally distributed. Related to post-test normality test on the control class of IAIN, 
Kolmogorov-Smirnov Sig value is 0,200 >0,05 and Shapiro Wilk Sig values is 0,221 >0,05; whereas post-test normality test on the experimental class of IAIN shows that Kolmogorov-Smirnov Sig value is 0,132 >0,05 and Shapiro Wilk Sig value is $0,061>0,05$. It means that post-test scores, either in control or experimental class, are in normal distribution. Based on normality pre-test on the control class of UNS, it is found that Kolmogorov-Smirnov Sig value is 0,200 > 0,05 and Shapiro Wilk Sig value is 0,391 >0,05; while on the experimental class, Kolmogorov-Smirnov Sig value is 0,200>0,05 and Shapiro Wilk Sig value is 0,398 $>0,05$. The pre-test scores on the control and experimental class of UNS are in normal distribution. In terms of normality post-test on the control class of UNS, Kolmogorov-Smirnov Sig value is 0,071>0,05 and Shapiro Wilk Sig value is $0,052>0,05$; whereas in terms of normality post-test on the experimental class of UNS, Kolmogorov-Smirnov Sig value is 0,200 $>0,05$ and Shapiro Wilk Sig value is 0,742>0,05. Both results show that post-test scores for either control or experimental class of UNS are normally distributed. Referring to homogeneity test done in IAIN; homogeneity pre-test Sig value is $0,173>0,05$ and homogeneity post-test Sig value is $0,731>0,05$. Thus, each class of IAIN is homogeneous. It is also found that in UNS; homogeneity pre-test Sig value is $0,880>0,05$ and homogeneity post-test Sig value is $0,328>0,05$. This indicates that each class of UNS is homogeneous. Therefore, it can be concluded that the undergraduates' pre-test and post-test scores of IAIN and UNS are homogeneous.

Based on the $t$-test on the pre-test done in IAIN, Sig. $(2$ tailed) is $0,495>0,05$ and $t$ value $(0,687)<t$ table $(2,0017)$ so $\mathrm{H}_{0}$ is accepted. It means that there is no difference between pre-test mean scores on the control and experimental class. The same finding is also obtained in terms of the $t$-test on the post-test done in IAIN. Sig. ( 2 tailed) is $0,005<0,05$ and $-\mathrm{t}$ value $(-2,901)<-\mathrm{t}$ table $(-2,0017)$. Hence, $\mathrm{H}_{0}$ is rejected. It show s that there is difference between post-test mean scores on the control and experimental class. Based on the $t$-test on the pre-test done in UNS, Sig. (2 tailed) is $0,221>0,05$ and $-t$ value $(-1,237) \geq-t$ tabel $(2,0017)$. Ho is accepted. It indicates that there is no difference between pre-test mean scores on the control and experimental class. Related to the $t$-test on the post-test, Sig. ( 2 tailed) shows that $0,000<0,05$ and $-t$ value $(-3,857)<-t$ table ($2,0017)$ so that $\mathrm{H}_{0}$ is rejected. This denotes that there is difference between post-test mean scores on the control and experimental class. The different mean scores between experimental and control class of both IAIN and UNS are caused by the treatment, the use of online learning information system on experimental class in macroeconomics learning.

Based on Gain test on the scores of IAIN's undergraduates, the data on the control class show that the undergraduates who are included in high criteria are $0 \%$, medium are $27 \%$, and low are $73 \%$. It means that there is no undergraduates in the control class who are considered having high criteria. On the experimental class of IAIN, the undergraduates who are included in high criteria are $3 \%$, medium are $67 \%$, and low are $30 \%$. Besides, in UNS, the data on the control class show that the undergraduates who are considered having high criteria are $0 \%$, medium are $60 \%$, and low are $40 \%$. This denotes that there is no undergraduates considered having high Gain criteria. On the experimental class of UNS, the undergraduates who are considered having high criteria are $0 \%$; it is the same as the data on the control class. How ever, those who are considered having medium Gain criteria are more than that of in the control class which is $83 \%$ and those who are considered having low Gain criteria is only $17 \%$. It can be said that the two experimental classes of IAIN and UNS have higher N-Gain than the control classes. Therefore, the implementation of online information system in experimental class improves the undergraduates' learning outcome better rather than the treatment done in control class.

\section{The Effectiveness of Learning Information System Media in Macroeconomics Learning to Im prove Critical Thinking Viewed from Questionnaire Filled by the Undergraduates}

The validity of the questionnaire in this research is measured by using Product Moment formula. This formula measures the correlation among items tow ards the total score in a questionnaire. It is found that $\mathrm{r}_{0}>$ $\mathrm{rt}_{\mathrm{t}}$ so that all questionnaireitems in this research are considered valid. Meanwhile, the reliability is measured through Alpha Cronbach with 0,07 as the minimum value. The measurement shows that Alpha value on the questionnaire is $0,929>0,70$. Thus, the questionnaire used as a research instrument in this reseach is reliable.

The result of Kolmogorov-Smirnov normality test is $0,200>0,05$. This shows that the data collected from the questionnaire are in normal distribution. F obtained from linearity test is 1,926 while $F$ table is 7,08 . $\mathrm{F}_{\mathrm{o}}$ is lower than $\mathrm{Ft}_{t}(\mathrm{Fo}<\mathrm{Ft})$. It denotes that web-based macroeconomics learning information system has 
linear and significant correlation towards critical thinking. From the heteroscedasticity test, the obtained value is $0,983>0,05$. There is no heteroscedasticity. The autocorrelation test used is Durbin Watson test. Durbin-Watson value obtained in this research is 2,192 while Durbin-Watson scale is 1,55. It means that $\mathrm{F}_{0}>$ $\mathrm{Ft}$; there is no autocorrelation.

Based on the result of simple regression analysis, equation $Y=52,578+1,247 \mathrm{X}$ can be formulated. $\mathrm{a}$ is the constants $(52,578)$ showing that $X$ (w eb-based macroeconomics learning information system) is constant. Hence, $\mathrm{Y}$ (critical thinking skills) is $52,578 . \mathrm{b} 1=1,247$. It means that if web-based macroeconomics learning information system increases 1 unit, critical thinking skills increases 1,247 unit.

The next analysis is autocorrelation analysis. Ro is $0,595>0,05$. The result indicates that there is significant and strong correlation between online learning information system and critical thinking skills. Coefficient of determination shows from $R$ square table is 0,355. Critical thinking skills $(Y)$ is $35,5 \%$ influenced by online learning information system while $64,5 \%$ of it is influenced by another factor that is not included as the research variable. Online learning information system interprets $35,5 \%$ of undergraduates critical thinking skills. This percentage is considered having high category to measure a certain factor. In summary, online learning information system is effective to improve undergraduates' critical thinking skills in learning macroeconomics.

\section{RESULT, DISCUSSION, AND SUGGESTIONS}

Based on the findings, it is proven that online learning contributes positively tow ards the learning outcome shown by the difference betw een the experimental and control groups. This finding strenghtens the research done by Kerdprasop and Kerdprasop (2008) showing that website is effective to improve the learning outcome since the materials can be repeated independently by the learners. Online-based learning process is interesting for the undergraduates to study the materials due to the variation of audio, video, visual, and text; so student-centered learning can be achieved (Sutopo, 2003:23; Kerdprasop, N. and Kerdprasop, K., 2008; Mccutcheon, Halloran, \& Lohan; 2018). Due to the multimedia element in online learning, the undergraduates' interest and attitude to study deeper can be achieved (Mccutcheon, Halloran, \& Lohan, 2018). Website-based learning eases the undergraduates to construct the materials through borderless information access independently (Wang et al. 2017) and to be active since they have their own accounts to access the materials anywhere and anytime. The website used in macroeconomics does not only include materials in it but also exercise, pre-test, and post-test so that the undergraduates can study the materials in one package. Mccutcheon, Halloran, \& Lohan (2018) say that web-based learning media that are integrated with material and evaluation help the undergraduates to construct the concept completely.

In order to improve the undergraduates' critical thinking, a real macroeconomic case study is included in the materials. This case study requires the undergraduates to whether agree or disagree tow ards certain information, evaluate the case to find a decision, and synthesize the data to generate new idea by relating the theories and the practices (Florea and Hurjui, 2015: 566; Samah, Hassan, Wahat, and Zaremohzzabieh, 2016: 122). This concept is supported by Zawilinski (2009: 660) who says that critical thinking can be improved by synthesizing online resources. Online learning also motivates the undergraduates to continue their learning since it can raise their curiousity; hence online learning can give deeper learning experience (Panigrahi, Srivastava, \& Sharma, 2018).

Online learning requires the undergraduates to do self-management and be independent through managing the time to finish the learning since they are not monitored by the lecturer (Davis et. al., 2018). The online teaching and learning process provides analytical and conceptual framew ork to self-manage since the materials are integrated in a single system (Tsai, 2014; Chan, 2012). Web-based online learning is proven able to realize student-centered learning so that the teaching and learning process can be more active and effective (Zhang, 2006). Based on the aforementioned notion, metacognitive, especially critical thinking, takes important role in online learning to achive the expected goal (Tsai et. al., 2018).

Based on the result of data analysis, it is concluded that online learning media are able to effectively improve the students' critical thinking as proven by the improvement of the undergraduates' learning outcome and survey distributed among the undergraduates. The findings are in line with the research conducted by Morris, N. P. (2010) and Kazu, I. Y., \& Demirkol, M. (2014), which show that blended learning 
can improve the learning outcome as well as the undergraduates' satisfaction in the class. Besides, research done by Korkmaz, O., \& Karakus, U. (2009), Saadé, R. G., Morin, D., \& Thomas, J. D. (2012), Wa nnapiroon, P. (2014), Jou, M., Lin, Y. T., \& Wu, D. W. (2016), Swart, R. (2017) show s that blended learning not only improves the learning outcome but also the undergraduates' critical thinking skills. Petchtone, P., \& Sumalee, C. (2014) prove that web-based online learning can improve the undergraduates' cognitive creativity and critical thinking skills.

The use of online information system in macroeconomics class is effective to improve the learning outcome as well as to encourage the undergraduates' critical thinking. The improvement of the learning outcome is proven by the $\mathrm{N}$-gain and t-test of experimental and control classes, while the correlation analy sis result shows that there is a strong and significant corelation between information system media and critical thinking. The limitation of using online information systems is that it takes longer time to connect computer devices with the internet at the beginning of learning. There are several recommendations that can be drawn from this research. For the other researchers, online information system learning can be developed further, for example providing forum as a place for the undergraduates to communicate and share between the undergraduates and the lecturer to establish more ideal online learning. For educators, in using learning media, the need of the undergraduates have to be taken into account more. For undergraduates, besides concerning on the macroeconomic issues, concerning the other economic issues are due, especially those related to the daily life.

\section{Acknowledgment}

LPPM UNS who has given financial support

Leadership and lecturers of Economics Department of IAIN Salatiga

\section{REFERENCES}

Ahrari, S., Samah, B. A., Hassan, Md. S. Hj. Bin., Wahat, N. W. A., dan Zaremohzzabieh, Z. (2016). Deepening critical thinking skills through civic engagement in Malaysian higher education. Thinking Skills and Creativity, 22, 121-128. doi: 10.1016/j.tsc.2016.09.009.

Akyüz, H. İ., \& Samsa, S. (2009). The effects of blended learning environment on the critical thinking skills of students. Procedia-Social and Behavioral Sciences, 1(1), 1744-1748. doi: 10.1016/j.sbspro.2009.01.308.

Arsyad, Azhar. (2007). Media Pembelajaran. Jakarta: PT Raja Grafindo Persada.

Alotaibi, K. N. (2013). The effects of blended learning on developing critical thinking skills. Education Journal, 2(4), 176-185. doi: 10.11648/j.edu.20130204.21.

Bensley, D. A. (1997). Critical thinking in psychology: A unified skills approach. Pacific Grove, CA: Brooks/Cole.

Chan, C. K. K. (2012). Co-regulation of learning in computer-supported collaborative learning environments: A discussion. Metacognition and Learning, 7(1), 63-73. doi: 10.1007/s11409-012-9086-z.

Collis, B. \& Van der Wende, M. (2002). Models of technology and change in higher education: An international comparative survey on the current and future uses of ICT in higher education. Enschede: CHEPS University of Twente.

Davis,D., Chen,G., Hauff,C. \& Hoube, G.J. (2018). Activating Learning at Scale. A Review of Innovations in Online Learning Strategies. Computers \& Education, 125, 327-44. doi: 10.1016/j.compedu.2018.05.019.

Dwyer, C. P., Hogan, M. J., \& Stewart, I. (2014). An integrated critical thinking framew ork for the 21st century. Thinking Skills and Creativity, 12, 43-52. doi: 10.1016/j.tsc.2013.12.004.

Frydenberg, M and Andone, D. (2016). Creating micro-videos to demonstrate technology learning and digital literacy. Interactive Technology and Smart Education, 13 (4), 261-273. doi: 10.1108/ITSE-09-20160030. 
Wardani,D.K., Martono,T., Pratomo,L.C., Rusydi,D.S.. \& Kusuma,D.H. (2019). Online learning in higher education to encourage critical thinking skills in the 21st century. International Journal of Educational Research Review, 4(2),146-153.

Fang, L., Chow, S. H., \& Soo, W. M. (2012). Framew ork for evaluating blended learning in a university public-speaking course in Singapore. In Blended Learning Environments for Adults: Evaluations and Frameworks (pp. 176-201). IGI Global.

Florea, N. N., dan Hurjui, E. (2015). Critical thinking in elementary school children. Procedia Social and Behavioral Sciences, 180, 565 - 572. doi: 10.1016/j.sbspro.2015.02.161.

Fox, H. (1994). Listening to the world: Cultural issues in academic writing. Urbana, IL: National Council of Teachers of English.

Hake, R. R. (1998). Interactive-engagement versus traditional methods: A six-thousand-student survey of mechanics test data for introductory physics courses. American Journal of Physics. doi: $10.1119 / 1.18809$.

Heidi, Yeen-Ju Tan, Mai Neo. (2015). Exploring the use of authentic learning strategies in designing blended learning environments: A Malaysian experience. Journal of Science \& Technology Policy Management. (6)2. 127-142. doi: 10.1108/JSTPM-01-2015-0004.

Jou, M., Lin, Y. T., \& Wu, D. W. (2016).Effect of a blended learning environment on student critical thinking and knowledge transformation. Interactive Learning Environments, 24(6), 1131-1147. doi: 10.1080/10494820.2014.961485.

Kazu, I. Y., \& Demirkol, M. (2014).Effect of blended learning environment model on high school students' academic achievement. Turkish Online Journal of Educational Technology-TOJET, 13(1), 78-87. Retrieved from https://eric.ed.gov/?id=EJ1018177.

Kerdprasop, N. \& Kerdprasop, K. (2008). Knowledge mining in web-based learning environments. International Journal of Social Sciences, 3(2), pp. 80-84. Retrieved from https://pdfs.semanticscholar.org/0a6c/ced2fcd2fd1f779cb97c986cebc7fe84e34d.pdf.

Korkmaz, O., \& Karakus, U. (2009).The impact of blended learning model on student attitudes towards geography course and their critical thinking dispositions and levels. Turkish Online Journal of Educational Technology-TOJET, 8(4), 51-63. Retrieved from https://eric.ed.gov/?id=EJ859497.

Marton, F., Hounsell, D., \& Entwistle, N. (1997). The experience of learning: Implications fo teaching and studying in higher education. Edinburgh: Scottish Academic Press.

Mccutcheon, K., Halloran,P.O. \& Lohan,M. (2018). Online Learning versus blended learning of clinical supervisee skills with pre-registration nursing students: A randomised controlled trial. International Journal of Nursing Studies 82(January 2017): 30-39. doi: 10.1016/j.ijnurstu.2018.02.005.

Morris, N. P. (2010). Blended learning approaches enhance student academic performance. In Proceedings of Enhancing Learning Experiences in Higher Education: International Conference. Hong Kong University. Retrieved from https://www.cetl.hku.hk/conference2010/pdf/Morris.pdf.

Munir.( 2008 ). Kurikulum Berbasis Teknologi Informasi dan Komunikasi. Bandung: Alfabeta.

Nabila, R. (2018). Hasil Nilai Uji Kompetensi Kelas H dan Kelas I. Institut Agama Islam Negeri Salatiga.

Nabila, R. (2018). Hasil Pengamatan dan Analisis Angket Studi Pendahuluan. Institut Agama Islam Negeri Salatiga.

Panigrahi, R., Srivastava,P.R. \& Sharma,D. (2018). International journal of information management online learning :Adoption, continuance, and learning outcome - A review of literature. International Journal of Information Management 43, 1-14.doi: 10.1016/j.ijinfomgt.2018.05.005.

Petchtone, P., \& Sumalee, C. (2014).The validation of web-based learning environment model to enhance cognitive skills and critical thinking for undergraduate students. Procedia-Social and Behavioral Sciences, 116, 669-673. doi: 10.1016/j.sbspro.2014.01.277.

Poon, W. C., Lock-Teng Low, K., \& Gun-Fie Yong, D. (2004). A study of Web-based learning (WBL) environment in Malaysia. International Journal of Educational Management, 18(6). doi: 374-385. 10.1108/09513540410554031. 
Wardani,D.K., Martono,T., Pratomo,L.C., Rusydi,D.S.. \& Kusuma,D.H. (2019). Online learning in higher education to encourage critical thinking skills in the 21st century. International Journal of Educational Research Review, 4(2),146-153.

Ramsden, P. (1992). Learning to teach in higher education. London: Kogan Page.

Saadé, R. G., Morin, D., \& Thomas, J. D. (2012).Critical thinking in E-learning environments. Computers in Human Behavior, 28(5), 1608-1617. doi: 10.1016/j.chb.2012.03.025.

Swart, R. (2017). Critical thinking instruction and technology enhanced learning from the student perspective: A mixed methods research study. Nurse education in practice, 23, 30-39. doi: 10.1016/j.nepr.2017.02.003.

Salleh, S. M., Tasir, Z., \& Shukor, N. A. (2012).Web-based simulation learning framew ork to enhance students' critical thinking skills. Procedia-Social and Behavioral Sciences, 64, 372-381. doi: 10.1016/j.sbspro.2012.11.044.

Singh, H., \& Reed, C. (2001). A white paper: Achieving success with blended learning. Centra software, 1, 111. doi: 10.1.1.114.821.

Stupple, E. J., Maratos, F. A., Elander, J., Hunt, T. E., Cheung, K. Y., \& Aubeeluck, A. V. (2017). Development of the Critical Thinking Toolkit (CriTT): A measure of student attitudes and beliefs about critical thinking. Thinking Skills and Creativity, 23,91-100. doi:10.1016/j.tsc.2016.11.007.

Sutopo, Ariesto Hadi. (2003). Multimedia Interaktif Dengan Flash. Yogyakarta: Graha Ilmu.

Tania, K.D., \& Ibrahim, A. (1). (2011). Pembelajaran Bahasa Inggris untuk anak-anak berbasis Multimedia: Prosiding KNTIA Konferensi Nasional Teknologi Informasi dan Aplikasinya, Palembang, 21-22 Oktober 2011. Palembang, Indonesia: Jurusan Sistem Informasi Fakultas Ilmu Komputer Universitas Sriwijaya.

Tsai, Chia-wen. 2014. Exploring the Effects of Online Team- Based Learning and Co-Regulated Learning on Students ' Development of Computing Skills. Interactive Learning Environments 24 (4). doi: 10.1080/10494820.2014.917106.

Tsai, Ya-hsun, Chien-hung Lin, Jon-chao Hong, and Kai-hsin Tai. (2018). Computers \& Education The e Ff Ects of Metacognition on Online Learning Interest and Continuance to Learn with MOOCs. Computers E Education 121, 18-29. doi: 10.1016/j.compedu.2018.02.011.

Van der Wal, A. (2000). Critical thinking as a core skill: Issues and discussion paper. Paper presented at the HERDSA Annual International Conference, Melbourne, Australia.

Wang, Minhong et al. (2017). The use of web-based collaborative concept mapping to support group learning and interaction in an online environment. The Internet and Higher Education 34, 28-40. doi: 10.1016/j.iheduc.2017.04.003.

Wannapiroon, P. (2014). Development of research-based blended learning model to enhance graduate students' research competency and critical thinking skills. Procedia-Social and behavioral sciences, 136, 486-490. doi: 10.1016/j.sbspro.2014.05.361.

Wardani, D.K. (2018). Hasil Nilai Uji Kompetensi Kelas A dan Kelas B. Universitas Sebelas Maret.

Wardani, D.K. (2018). Hasil Pengamatan dan Analisis Angket Studi Pendahuluan. Universitas Sebelas Maret.

Zawilinski, L. (2009). HOT blogging: A framew ork for blogging to promote higher order thinking. The Reading Teacher, 62 (8), 650 - 661. doi: 10.1598/RT.62.8.3.

Zhang, L. (2006). Effectively incorporating instructional media into website based information literacy. The Electronic Library, 24(3), 294 - 306. doi: 10.1108/0264047061. 